\begin{abstract}
THE CHALLENGES OF PLANNING FOR RURAL CHARACTER: A CASE STUDY FROM EXURBAN SOUTHERN NEW ENGLAND
\end{abstract}

\author{
By Matthew J. Zabik
}

Two decades after Randall Arendt's landmark work Rural by Design: Maintaining Small Town Character was first published, exurban New England continues to struggle with sprawl and loss of rural character. Recently, Ryan (2002), Ryan (2006), and Walker and Ryan (2008) have attempted to understand how resident perceptions of landscape features can help both preserve rural character and accommodate new development in nearby Massachusetts and Maine. Using the case study of Stafford, Connecticut, this study employs focus groups and interviews to assess the potential challenges of planning for rural character in exurban New England. Results suggest that planning for rural character continues to be difficult, especially in some working-class exurban communities with limited planning traditions. More importantly, this study emphasizes the need for further collaborative learning to address how rural character planning approaches may be implemented in those places that perhaps need them most. 


\title{
THE CHALLENGES OF PLANNING FOR RURAL CHARACTER: A CASE STUDY FROM EXURBAN SOUTHERN NEW ENGLAND
}

\author{
A Thesis \\ Submitted to the \\ Faculty of Miami University \\ in partial fulfillment of \\ the requirements for the degree of \\ Masters of Arts \\ Department of Geography \\ by \\ Matthew J. Zabik \\ Miami University \\ Oxford, Ohio \\ 2010 \\ Advisor Dr. David L. Prytherch \\ Reader Dr. James M. Rubenstein \\ Reader Ms. Robbyn J.F. Abbitt
}




\section{TABLE OF CONTENTS}

$\begin{array}{ll}\text { INTRODUCTION } & 01\end{array}$

$\begin{array}{ll}\text { BACKGROUND } & 03\end{array}$

Exurban Development and Rural Sprawl 03

Rural Character Landscape Preferences and Planning 04

CASE STUDY 06

RESEARCH FOCUS $\quad 08$

$\begin{array}{ll}\text { RESEARCH METHODS } & 09\end{array}$

GIS Analysis: Development Patterns between 1980 and $2008 \quad 09$

Focus Groups: Gauging Perceptions of Rural Character 10

Semi-Structured Interviews and Participant Observations 12

RESULTS 12

GIS Analysis: Temporal and Spatial Changes in Development 12

Focus Groups: Perceptions of Change and Rural Character 18

$\begin{array}{ll}\text { Perceptions of Development Change } & 18\end{array}$

Rural Character Means Different Things to Different People 19

Compatible Rural Residential Development 21

Concern about Sprawl, Unsure about Planning $\quad 22$

Interviews and Observations: Moving Forward to Plan for Rural Character $\quad 24$

$\begin{array}{ll}\text { DISCUSSION } & 26\end{array}$

Challenges of Planning for Rural Character in Exurban New England 26

Collaborative Learning Implications $\quad 30$

CONCLUSION 32

REFERENCES CITED $\quad 34$ 


\section{LIST OF TABLES AND GRAPHS}

TABLE 1 (FIGURE 2)

2000 US Census Income and House Value Statistics

GRAPH 1 (FIGURE 7)

13

Population Change and Home Construction (Stafford, CT 1940-2008) 


\section{LIST OF FIGURES}

FIGURE 1 (MAP)

Location Map of Stafford, Connecticut

FIGURE 2 (TABLE)

08

2000 US Census Income and House Value Statistics

FIGURE 3 (PHOTO)

Rural Dirt Road Residential Development

FIGURE 4 (PHOTO)

Large Lot Upper Middle Class Subdivision

FIGURE 5 (PHOTO)

Higher Density Cluster Development

FIGURE 6 (PHOTO)

Subdivision on Mountain Fragmenting Forest

FIGURE 7 (GRAPH)

Population Change and Home Construction (Stafford, CT 1940-2008)

FIGURE 8 (MAP)

Town of Stafford Inventory of Dwellings and Open Space Lands

FIGURE 9 (MAP)

Town of Stafford Development Change for Dwellings (1980-2008)

FIGURE 10 (MAP)

Town of Stafford Areas of Greatest Development Change (1980-2008) 


\section{DEDICATION}

I dedicate this research to my family, hardworking rural residents and farmers everywhere, and those people who work tirelessly against all odds to conserve the valuable natural resources and traditions of rural America. Without the inspiration and support of my parents, I would have never made it to where I am today. Growing up in a rural area threatened by immense development change made me recognize at an early age the need for proactive planning, as well as the importance of neighbors coming together to help preserve a lasting vestige of rural character. For me, the true spirit of this great country lies in the people and landscapes of rural America. To quote President Theodore Roosevelt, "Conservation means development as much as it does protection." While progress and new development is important, we must also remember our roots and conserve the landscapes that honor our heritage. 


\section{ACKNOWLEDGEMENTS}

I would sincerely like to thank my thesis advisor, Dr. David Prytherch, for all of his guidance, direction, advice, and wisdom throughout the duration of this project. Without the financial support of the Miami University Graduate School and the Department of Geography, completing this thesis would have never been possible. Thank You! I would also like to thank Thesis Committee Members Dr. Jim Rubenstein and Ms. Robbyn Abbitt for their advice, direction, and constructive criticism. Most importantly, I want to thank the Stafford Selectman's Office, Plan of Conservation and Development Advisory Committee, Open Space Advisory Committee, Norcross Wildlife Sanctuary Foundation, The Trust for Public Land, The Trustees of the Reservation, the Connecticut Department of Environmental Protection, and the many town officials, residents, and landowners from Stafford, Connecticut who graciously agreed to participate in this study. 


\section{INTRODUCTION}

Low-density residential and commercial strip development along arterial highways scattered outside of existing villages, town centers, and cities is a ubiquitous phenomenon experienced all across the United States. In Connecticut, for example, despite modest population growth, widespread low-density exurban development threatens to destroy the picturesque rural landscapes widely valued by both local residents and tourists (CT CAD Plan, 2005). Referred to as rural sprawl by some researchers (Daniels, 1999; Hasse and Lathrop, 2003; Hasse, 2004), the problems of rapid low-density leapfrog rural development are diverse. From environmental problems associated with private septic tanks and groundwater wells to growing demands for new infrastructure and public services, improperly-planned, impulsive, and haphazard rural development has the potential to drive up land costs, increase taxes, and put traditional natural resource businesses such as farming, forestry, and mining in conflict with new residents (Daniels, 1999).

In response to increased development pressures over the past two decades, some New England municipalities have embraced the concepts of conservation development introduced by Randall Arendt et al. in the 1994 landmark work Rural by Design: Maintaining Small Town Character. While these ideas were first incorporated into the landscapes of the Connecticut River Valley of Western Massachusetts, this innovative concept of planning for rural character has since spread to other regions of the United States as well. Recent papers (Ryan, 2002; Ryan, 2006; Walker and Ryan, 2008) have explored issues pertaining to residential development and rural character in Massachusetts and Maine, specifically examining concepts of place attachment, landscape preservation, and alternative development strategies. Nonetheless, some other communities in New England continue to struggle with sprawl and loss of rural character nearly two decades later. Why? Using the case study of Stafford, Connecticut, this study asks: "What are the challenges of planning for rural character in exurban New England?" Although the work of Arendt and others in this field have dramatically changed the way in which some towns plan, more work may be needed to understand the limits to rural character planning approaches in those exurban communities that would seem to benefit from them most. 
Consequently, this study endeavors to examine the existing boundaries and future obstacles that stand in the way of planning for rural character, specifically in New England.

Stafford Connecticut contains some of the last remaining rural landscapes between Boston and New York City, despite being in one of the most densely populated areas in the United States. To investigate residential development patterns in exurban Southern New England, this study first employed Geographic Information Systems (GIS) to analyze and document spatial patterns of development change between 1980 and 2008. More importantly, to understand the challenges of planning for rural character and engage the community on the meaning of rural character, this study used focus groups and interviews where town stakeholders discussed development change, landscape preferences, and opinions concerning municipal planning. Time was also spent working collaboratively with local land use planning committees.

As in other areas of Southern New England, Stafford has seen a generally modest and consistent pattern of residential development between 1980 and 2008, with periodic spikes during more economically favorable times. Spatially, home building has occurred wherever there is available land with a willing seller and buyer (developer). Some decades such as the 1990s, for example, even saw new home construction and other spatial land use change outpace population growth. Thus, while the quantity of development may not be overwhelming, the lowdensity distribution of new housing in outlying areas is functionally inefficient, increasing costs for government services, and rapidly altering the rural character of the area. Nonetheless, results suggest that place attachment surveys, focus groups, and conservation initiatives may not always be enough to advance land use policy changes. Sometimes financial constraints, worries about future tax revenues, and desires for economic growth outweigh issues of land conservation, historic preservation, and environmental sustainability in exurban working class communities. While the planning and geographical literature offers helpful insight on how to plan for rural character, much of this literature does not address the initial challenges of convincing residents and stakeholders that unplanned development can be harmful for their town. Consequently, this research emphasizes the need for increased collaborative learning on issues related to exurban planning, specifically at the initial stages where promoting educational awareness of both the misconceptions and benefits of planning may be integral to attaining public support. 


\section{BACKGROUND}

\section{Exurban Development and Rural Sprawl}

Although sprawl has gained tremendous academic and popular attention, defining and delineating it remains a major challenge (Dowling, 2000). The geographic and planning literatures typically focus on the (1) causes, (2) effects, or (3) spatial and temporal delineation of sprawl (Torrens, 2008; Wolman et al., 2005). Rural sprawl, defined as lower density leapfrogging development patterns diffusely located in the countryside outside existing village, town, or city centers, on the other hand, is often a lesser studied, but equally important phenomenon (Daniels, 1999). Landscape preference studies suggest that an increasing number of Americans prefer to live in urban-rural fringe areas (Dowling, 2000; Ryan, 2002; Sullivan, 1994; Walker and Ryan, 2008) or vacation and retire near lakes or other natural amenity-rich regions (Gonzalez-Abraham et al., 2007). While many people can describe the negative effects of sprawl in their local communities, there is little consensus, however, on how to best measure this complex and highly variable phenomenon (Dowling, 2000; Torrens, 2008). Some researchers focus instead on development changes and patterns (Hoffhine et al., 2003).

Even if literature on sprawl has become quite large, relatively few studies examine the complex land use patterns and dilemmas particular to the northeastern United States, and regions like New England where nonagricultural exurban areas fringe well-established decaying central cities (Hamin et al., 2006). Unlike the West and Midwest, which historically has had access to more undeveloped agricultural land in unincorporated townships, high population density and limited availability of land has plagued southern New England for decades. The close spatial arrangement of diverse land uses and activities, coupled with a highly fragmented political landscape (Hamin et al., 2006), prompted many municipalities several decades ago to adopt exclusionary two to three acre large-lot zoning ordinances designed to preserve some vestige of rural character. Widespread use of this zoning technique may facilitate diffuse low-density growth patterns (Daniels, 1999) and actually hide the magnitude and extent of sprawl. The subtle spatial and temporal patterns of land use change in New England may blend better into the surrounding landscape and consequently obscure the scope of urban development and change. 


\section{Rural Character Landscape Preferences and Planning}

To understand the dynamics of exurban development, it is important first to examine the landscape features people perceive as being rural and how new development may affect those landscapes. Because landscape and consumer preferences may fuel new development, effective planning needs to first identify what people find most attractive in the landscape. In simplest terms, rural character describes peoples' visual or cogitative perceptions of both natural and developed landscapes (Ryan, 2002; Ryan, 2006; Tilt et al., 2007; Walker and Ryan, 2008). Rural character is also synonymous to a "sense of place" and represents an attitude concerning one's environs (Walker and Ryan, 2008). Nonetheless, the basic problem or limitation with rural character studies is that it is inherently a function of personal, local, and regional bias (Tilt et al., 2007). Despite being subject to regional differences and even personal bias among adjacent neighbors (Sullivan, 1994), using rural character perceptions at the discrete municipal level can be an effective planning tool to help deal with development pressures. While some researchers believe that municipal-based planning unduly constrains local governments and is largely ineffective when dealing with regional issues, local regulations and planning methods are more likely to overcome legal challenges successfully than complex statewide plans meeting more fervent and widespread opposition. More importantly, people are more likely to see the positive effects of local planning efforts and therefore support them if they feel that they have a stake in their community's vision of the future.

Responding to the challenges of balancing development with rural character, planning scholar Randall Arendt is widely known for making the concept of conservation development mainstream within the realm of rural planning. In simplest terms, conservation development considers pre-existing physical and environmental conditions before implementing alternative site design and building techniques like clustering housing in an attempt to preserve rural character and protect environmentally sensitive lands and contiguous tracts of forest or agricultural land (Arendt et al., 1994). In the landmark text Rural by Design: Maintaining Small Town Character, Arendt et al. offered both hypothetical and real world examples of alternative development designs such as conservation subdivisions and cluster development that attempt to preserve rural character. Speaking directly to small town America, Arendt (1999) also presented the necessary planning procedures and legal measures needed for municipalities to implement 
conservation development in Growing Greener: Putting Conservation into Local Plans and Ordinances. The innovative work of Arendt has encouraged a plethora of additional research on how to better plan for rural character.

Ryan (2002, 2006), who now works in the same region where Arendt got started nearly two decades ago, has documented how understanding resident perceptions of landscape features can help both preserve rural character and accommodate new development. Performing much of this research in the Western Massachusetts towns of Amherst and Sunderland, approximately 30 miles and 50 miles north of Connecticut, respectively, the research was more than just an assessment of existing rural conditions. Using photo-questionnaires to gauge how residents view alternative forms of development such as clustered subdivisions and conservation subdivisions, survey results found that rural character is not simply synonymous with environmental preservation (Ryan, 2002). While preserving large continuous tracts of undeveloped land may be essential to maintaining a working landscape that embodies the traditional rural paradigm (Daniels, 1999; Arendt et al., 1994), more importantly, preserving rural character involves integrating the community's preferences with the goals of both government and developers (Arendt et al., 1994).

It is now established among scholars, planners, and many New England residents that landscape preferences should be incorporated into rural planning, especially in those places where high social value is placed on aesthetics and community character. Additional survey results determined that residents from these New England towns preferred new development that conserved land along existing rural roadways to shield development from public avenues (Ryan, 2002). Most importantly, keeping mature vegetation, visible agricultural lands, and development styles that were consistent with traditional New England designs were considered most appropriate when maintaining the rural atmosphere (Ryan, 2002). Although many residents valued natural features and open agricultural fields, long-time residents had a stronger connection with cultural features, possibly through years of social interactions, than newer residential transplants (Ryan, 2002). Rural residents who lived on small lots ( $<2$ acres) viewed subdivisions more favorably than large-lot rural residents who noticed the negative effects of development more readily (Ryan, 2002). When discussing rural development, many developers 
stated that they would be more willing to build to the community's expectations if the government provided fewer restrictions (Ryan, 2006). An additional New England study focusing on place attachment in rural Maine by Walker and Ryan (2008) found that residents who perceived development as being a problem were more likely to support conservation and growth management initiatives. This study supports the previous findings of Ryan (2002), suggesting that residents with more land tended to notice new development more than small lot residents did and were less receptive to cluster development subdivisions outside of village centers (Walker and Ryan, 2008).

The rural character literature (Arendt et al., 1994; Ryan, 2002; Ryan, 2006; Walker and Ryan, 2008) emphasizes the importance of incorporating landscape preferences and perceptions of rural character change into the local planning process. Nonetheless, the challenge is putting these ideas into practice. While pioneers such as Randall Arendt introduced revolutionary landscape architecture and subdivision designs aimed at preserving rural character more than two decades ago in the Connecticut River Valley of Western Massachusetts at the very heart of New England, its implementation has hardly been universal. Research suggests that support for preserving rural character, at least in rural New England, is highly contingent on whether residents recognize development change and if that change is perceived to be a problem. This, however, highlights the importance of using communicative planning techniques like focus groups, surveys, and semi-structured interviews (Ryan, 2002; Ryan, 2006; Walker and Ryan, 2008) to engage rural communities about the alternatives to sprawling exurban development.

\section{CASE STUDY}

A good way to assess the use of and challenges to planning for rural character is to look at exurban New England communities confronting development change. Past spatial and temporal patterns of development and political fragmentation in New England exemplify the potential challenges of studying exurban sprawl and rural character. As one of the most densely populated areas of the United States, the state of Connecticut is at the center of the "New Atlantic Triangle", which is a unique cluster of five metropolitan regions anchored by the New York, Boston and Albany metropolitan areas (CT CAD Plan, 2005). Nonetheless, northeast 
Connecticut continues to have a diverse landscape of large contiguous tracts of forestland surrounded by small farms, historic town greens, and mill towns dating back to the Industrial Revolution. Located in northeast Connecticut, the case study town of Stafford is approximately 15-40 minutes away by automobile from the urban centers of Springfield, Massachusetts, Hartford, Connecticut, Worcester, Massachusetts, numerous suburban shopping centers, and the main campus of the University of Connecticut at Storrs (figure 1). Surrounded by three major interstate highways, Stafford is situated in northern Tolland County along the Massachusetts border. The only town in Connecticut that does not belong to a regional planning commission, the town of Stafford is predominantly a working class community. In 2000, Stafford's median household income, per capital income, and medium housing value was noticeably lower than many surrounding towns or even the Connecticut state average (figure 2).

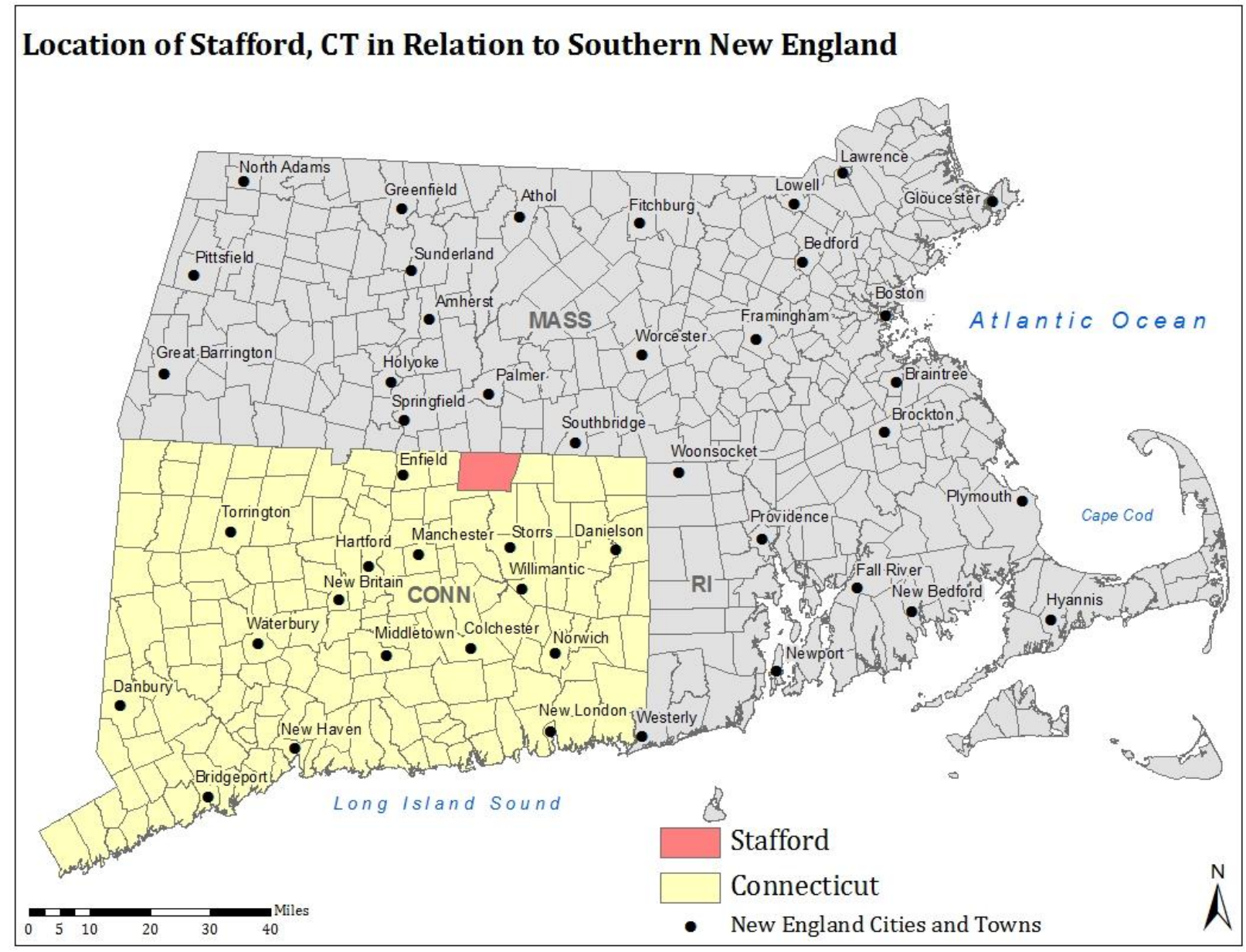

Figure 1. Location of Stafford, CT (highlighted red) in relation to Southern New England. 
Stafford is the third largest town in area in Connecticut at approximately 58 square miles. From large contiguous blocks of public and private forestland and small farms to several historic mill town centers, the town represents a microcosm of the diverse landscape features that comprise Southern New England. Surrounded by affluent suburban municipalities with more restrictive land use regulations, the town's abundant and affordable land and easy access to a variety of metropolitan markets makes it an attractive choice for people seeking to escape the cities and suburbs. Because the price of housing has increased and the availability of land has decreased in these neighboring communities, the State of Connecticut believes that Stafford has already become the next ring of suburban development emanating east from Hartford (CERC, 2006). Stafford contains some of the last remaining rural landscapes between Boston and New York City. Its close proximity to urban-suburban areas and major transportation networks, however, makes Stafford likely to see more intensive residential development, especially when 60 percent of 90-acre or larger woodland parcels are unprotected and owned by nonresidents (Town of Stafford Draft Plan of Conservation and Development, 2009). Despite being on the doorstep of Arendt's conservation development movement, Stafford continues to struggle with low-density diffuse residential housing growth altering rural character.

\begin{tabular}{|l|l|l|l|}
\hline Town & $\begin{array}{l}\text { Median Household } \\
\text { Income }\end{array}$ & $\begin{array}{l}\text { Per Capital } \\
\text { Income }\end{array}$ & Median Housing Value \\
\hline Stafford & $\mathbf{\$ 5 2 , 6 9 9}$ & $\mathbf{\$ 2 2 , 0 1 7}$ & $\mathbf{1 2 7 , 5 0 0}$ \\
\hline Somers & $\$ 65,275$ & $\$ 29,128$ & $\$ 193,900$ \\
\hline Ellington & $\$ 62,405$ & $\$ 27,776$ & $\$ 158,000$ \\
\hline Willington & $\$ 51,690$ & $\$ 27,062$ & $\$ 141,200$ \\
\hline Union & $\$ 58,214$ & $\$ 27,900$ & $\$ 141,400$ \\
\hline State of CT & $\$ 53,935$ & $\$ 28,766$ & $\$ 169,900$ \\
\hline Tolland County & $\$ 59,044$ & $\$ 25,474$ & $\$ 150,500$ \\
\hline
\end{tabular}

Figure 2. United States Census Bureau (2000) statistics for Stafford and surrounding towns.

\section{RESEARCH FOCUS}

While Arendt, Ryan, and others have offered innovative alternatives to sprawling rural development, many areas of New England continue to struggle with the loss of rural character. Using the case study municipality of Stafford, Connecticut, this study first examines development patterns between 1980 and 2008 to see if rural sprawl is indeed a problem and if alternative development techniques like conservation development are being employed. More 
importantly, however, this study endeavors to examine the challenges of planning for rural character in exurban New England, particularly in areas unfamiliar with proactive comprehensive planning. Using focus groups, semi-structured interviews, and participant observations to gauge peoples' perceptions of development change and rural character, this study emphasizes the need for further collaborative learning to address how rural character planning approaches may be implemented in those places that perhaps need them most.

\section{RESEARCH METHODS}

\section{GIS Analysis: Development Patterns between 1980 and 2008}

Understanding the effects of exurban development on rural character and the landscape first requires an objective analysis of past development patterns and an inventory of existing conditions. Because there is a general lack of consensus over how to quantify and measure sprawl (Torrens, 2008), some researchers only measure development change (Hoffhine et al., 2003). Remote sensed Landsat imagery, while helpful when measuring land use cover, vegetation, and impervious surface change, is most appropriate for characterizing development over large regional areas (Epstein et al., 2002). The lower resolution Landsat imagery is not effective for smaller scale studies at the municipal level. Therefore, development change for the case study town of Stafford, Connecticut was modeled using aerial photography and spatial analyst tools in the ESRI ArcGIS 9.3 software.

Several researchers have created geospatial metrics (i.e. housing density, accessibility to community nodes, highway strip development, loss of valuable or vulnerable land resources, and encroachment on existing open space) that can be used to quantify the degree of sprawl and exurban development using ArcGIS (Crawford, 2007; Hasse, 2004; Hasse and Lathrop, 2003). For the purposes of this study, however, the GIS analysis primarily focused on the temporal and spatial changes of (1) dwelling units and (2) new subdivision road construction, two metrics espoused by Epstein et al. (2002) and Hasse (2004). Dwelling units were digitized from digital 1980 USGS topographic map quadrangles and 1990, 2004, 2006, and 2008 aerial imagery datasets. New subdivision roads were also digitized from the topographic map and aerial 
imagery datasets. New housing and road construction was used as a simple proxy to estimate development change between 1980 and 2008.

\section{Focus Groups: Gauging Perceptions of Rural Character}

According to the rural planning literature, focus groups are a good method to gauge perceptions of development change, rural character, landscape preferences, and thoughts concerning planning. For the research study, three focus group sessions open to all residents and landowners were held at the town library. The focus group forum consisted of three parts: (1) new development compatibility and perceptions of community character, (2) existing town landscapes, and (3) the future landscape of Stafford. Participants first viewed eight photographs of four different types of development scenes found in several nearby towns with development patterns similar to Stafford. They were then asked to rank their preference for each development scene on a 5-point Likert scale (1-strongly dislike, 2-dislike, 3-neutral, 4-prefer, and 5-strongly prefer) (Ryan, 2006). In addition, participants were asked whether each scene was compatible or incompatible with the character of Stafford (1-highly incompatible, 2-incompartible, 3-not sure, 4-compatible, and 5-very compatible) (Ryan, 2006). While many of the landscape preference photo questionnaires employed by Ryan (2002), Ryan (2006), Sullivan (1994), and Walker and Ryan (2008) only used ground photographs of landscapes, each location for this particular study was represented by both a ground and aerial photograph to encourage discussion about the larger scale spatial impact of development change. Participants in the focus group were asked whether having a wider perspective or aerial view of a development changed their preference or compatibility rating. Location A consisted of new homes built along a rural dirt road (figure 3), B showed a large-lot subdivision with cul-de-sac road (figure 4), C was a higher density cluster development with sidewalks built on a farm field (figure 5), and D exhibited a conventional large-lot subdivision craved out on the top of a mountain (figure 6).

The second part of the focus group consisted of a discussion of specific locations within the town of Stafford that people felt were compatible or incompatible with Stafford's character. A successful technique commonly used by planners, this part of the focus group also included discussions why certain areas are desirable or undesirable and what could be done to ameliorate an undesirable area. In the remaining time, the group discussed how Stafford's landscape might 
change in the next twenty years. This helped to better comprehend features that the community valued, as well as aiding future planning endeavors by helping elected officials and land use committee members understand potential residential land use preferences. This process emphasized the importance of civic and engaged scholarship in geography and planning.

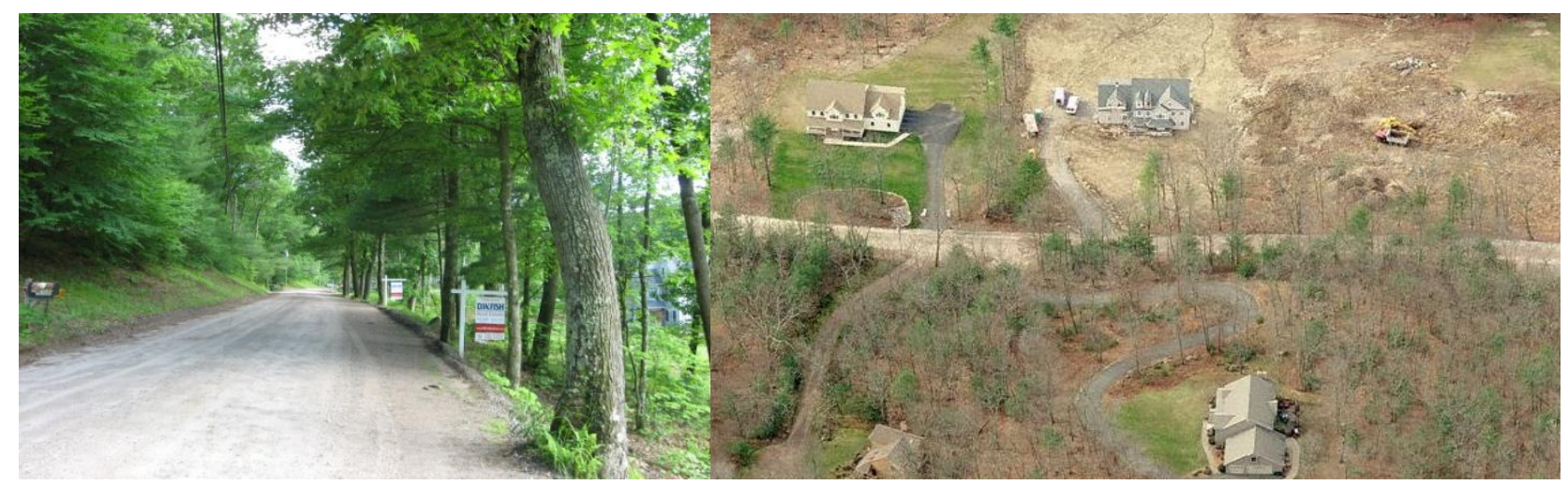

Figure 3. Building lots for sale on what used to be a rural dirt road now populated with large suburban style homes. (Location A)

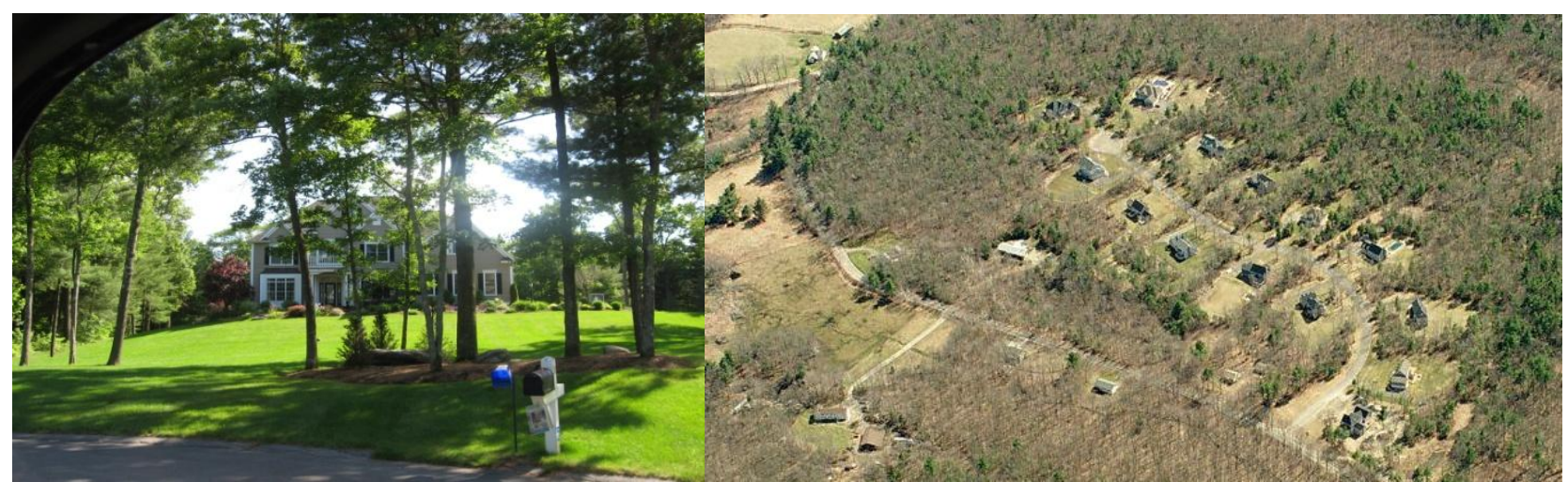

Figure 4. Conventional upper-middle class large-lot subdivision with dead end cul-de-sac near farmland. (Location B)

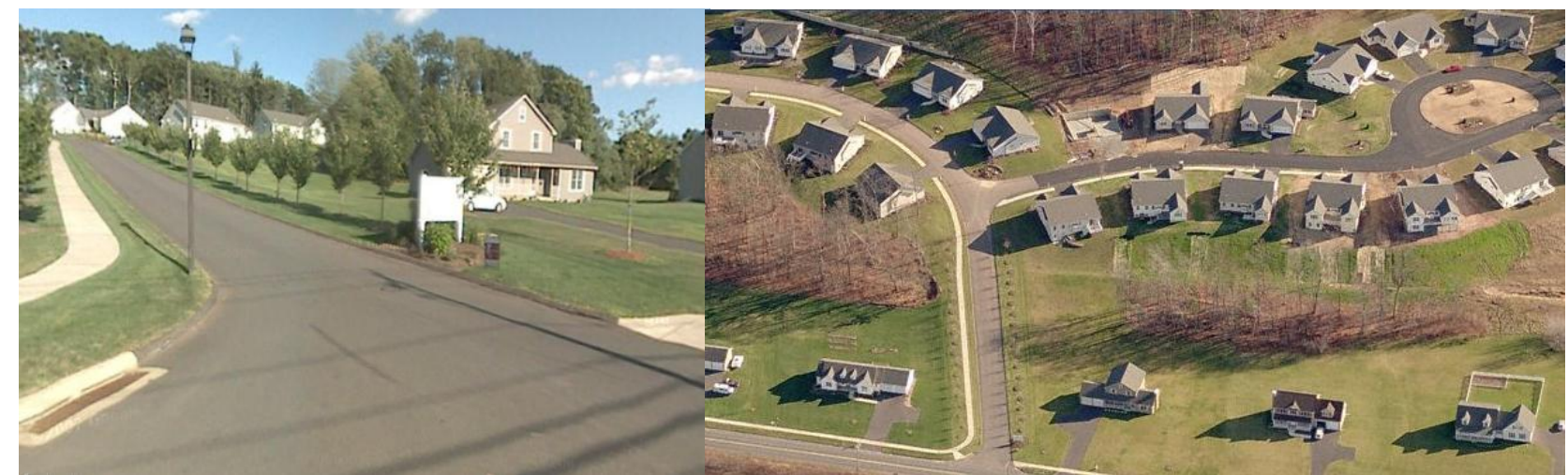

Figure 5. Higher density suburban cluster development with sidewalks. (Location C) 


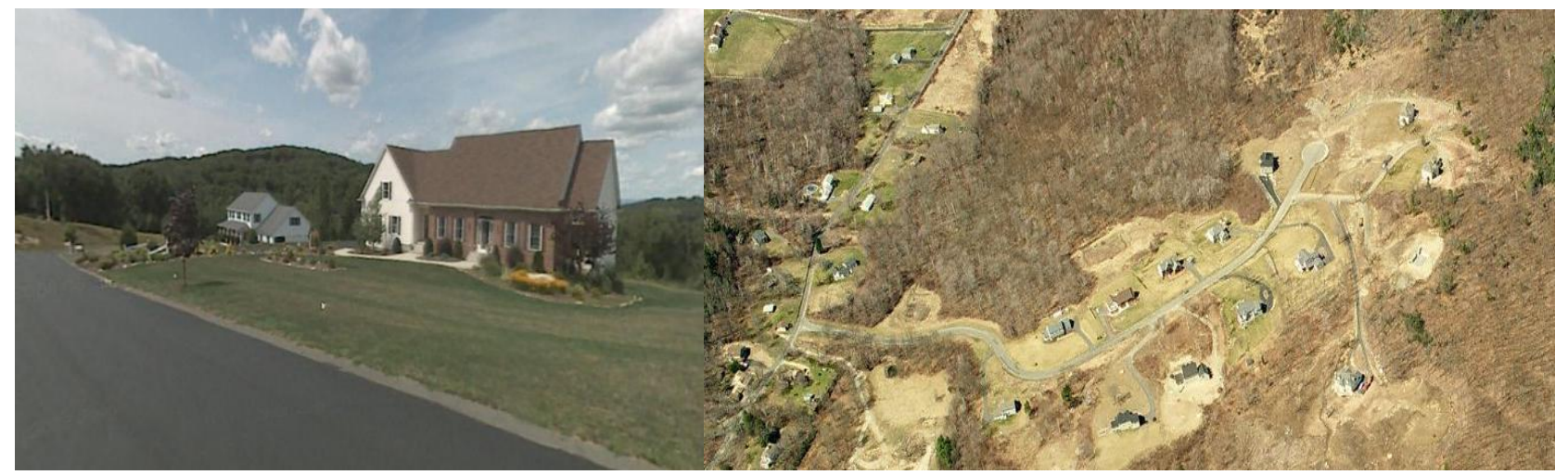

Figure 6. Large-lot subdivision placed on top of a mountain and located at the end of a country road. (Location D)

\section{$\underline{\text { Semi-Structured Interviews and Participant Observations }}$}

Other accepted methods for gauging landscape perceptions and preferences include semistructured interviews and participant observations. To supplement the results of the focus groups, individuals from different stakeholders groups such as engaged residents and landowners, local town officials and elected representatives, builders, developers, real estate professionals, and community volunteers and land use committee members were interviewed. The interviews allowed stakeholders to discuss the positive and negative effects of new development and make suggestions that could potentially enhance future municipal land use planning. Although most interviews were informal in nature, most conversations discussed valuable landscape characteristics, recent development and landscape changes, issues of compatible development, and the positive and negative effects or consequences of new development. Time was also spent attending meetings of the Town of Stafford Planning and Zoning Commission, Plan of Conservation and Development Advisory Committee, and Open Space Advisory Committee, as well as interacting with local residents in an informal and unintimidating manner.

\section{RESULTS}

\section{GIS Analysis: Temporal and Spatial Changes in Development}

Similar to other New England towns, GIS analysis shows that Stafford has experienced increased low-density decentralized residential development that may be characterized as rural sprawl, as defined by Daniels (1999) and Hasse and Lathrop (2003). While Census Bureau and 
town records show moderate population growth, these figures do not fully explain the spatial variability of landscape change, especially increasing patterns of diffuse exurban development (figure 7). Overall, this analysis shows a generally modest and consistent pattern of residential development between 1980 and 2008, with periodic spikes during more economically favorable times. For example, many of the larger subdivisions with more than one road or entry point were constructed during the more favorable real estate conditions of the late 1980s. More recently, five new subdivisions were developed within a two-year period between 2004 and 2006 at the height of the most recent real estate market boom.

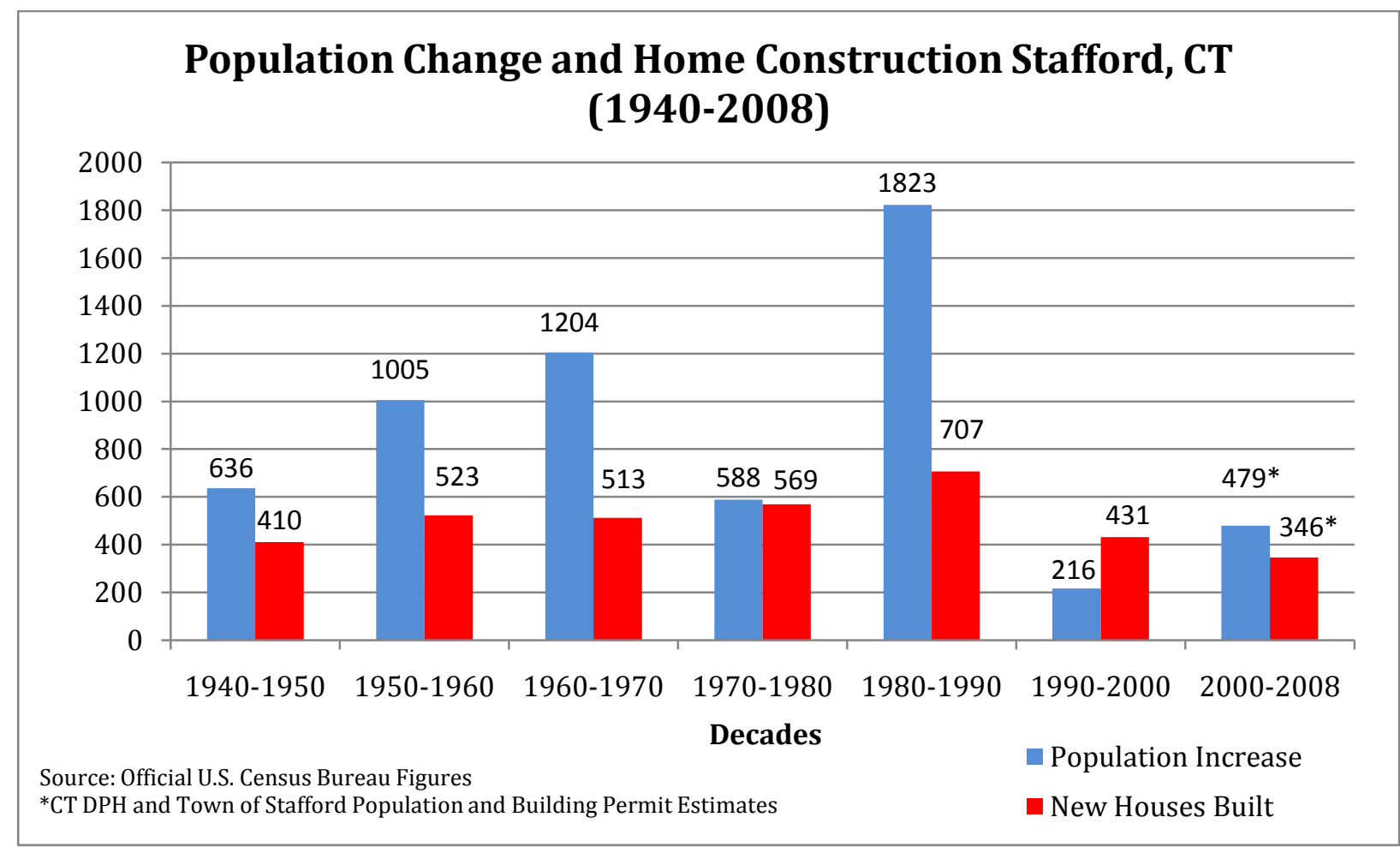

Figure 7. Stafford exemplifies the modern challenges of diffuse exurban development where spatial change often outpaces population increase (note the 1970s and 1990s). Thus, even when population growth is modest, more single-family dwellings sometimes continue to be built. On average, approximately 500 houses were built every ten years between 1940 and 2008.

Spatially, home building appears to occur wherever there is available land with a willing seller and buyer (developer). Thus, while the quantity of development may not be as overwhelming as in other areas of the United States or New England, the more rural areas of Stafford are nonetheless seeing dramatic changes wherever and whenever a landowner chooses to sell his or her land (figures 8 and 9). Spatial analysis shows that in 1980, most development was concentrated in the urban center of Stafford Springs and several other smaller villages. 
Between 1980 and 2008, the majority of development occurred along existing country roads, including several dirt roads where houses were sometimes built every 200 feet (figure 10). The type of development that is occurring in Stafford is clearly not representative of Arendt-style conservation development. Large areas in the northwest, northeast, and southeast corners of Stafford experienced little or no development change between 1980 and 2008. Despite the presence of state forest properties in those areas, there are a number of large privately owned potentially developable parcels over 90 acres that remain undeveloped. 


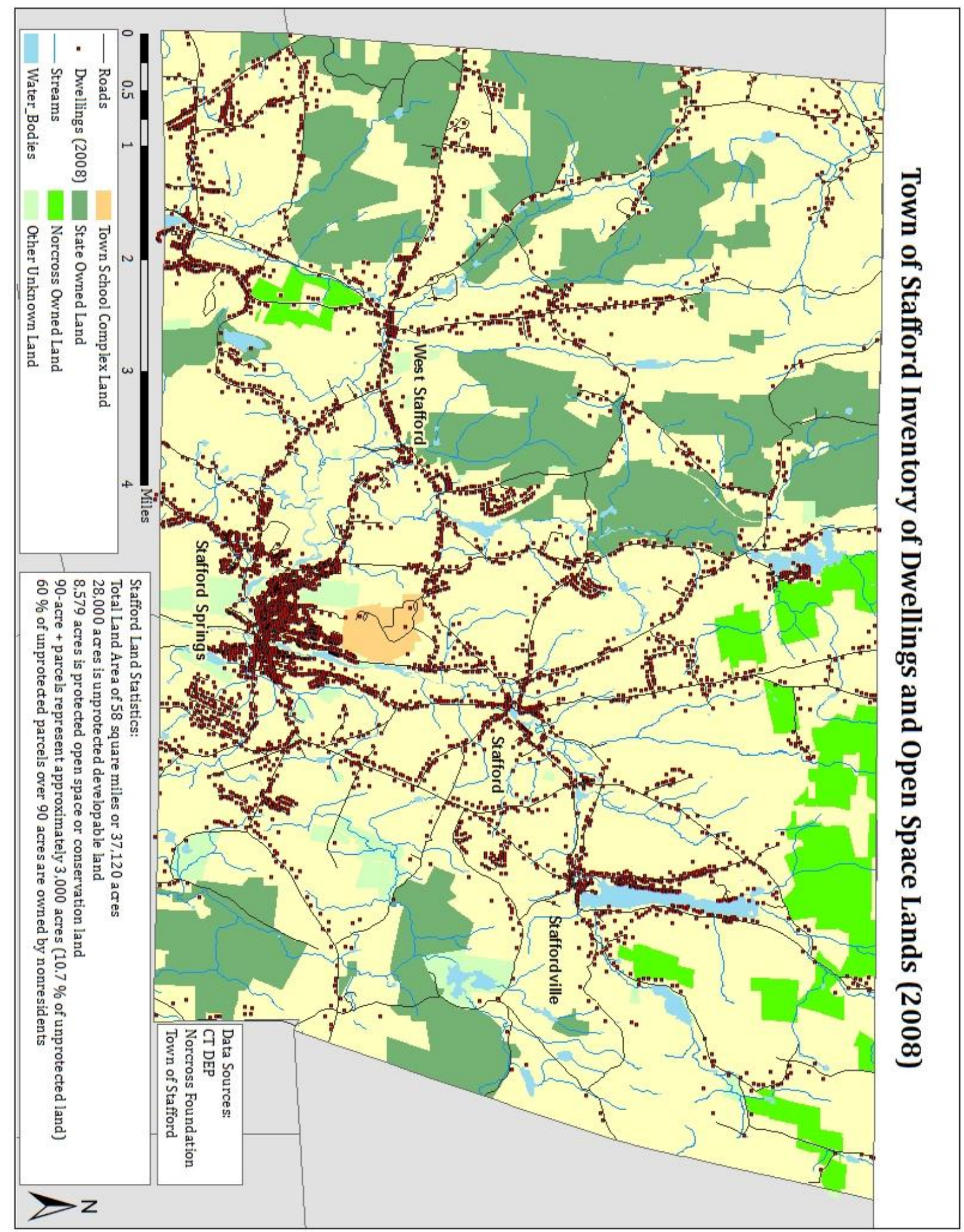

Figure 8. Although Stafford has 8,579 acres dedicated to open space, 60-percent of large parcels over 90 -acres are owned by nonresidents. More importantly, a significant portion of this privately owned land is also adjacent to or in between existing conservation lands. 


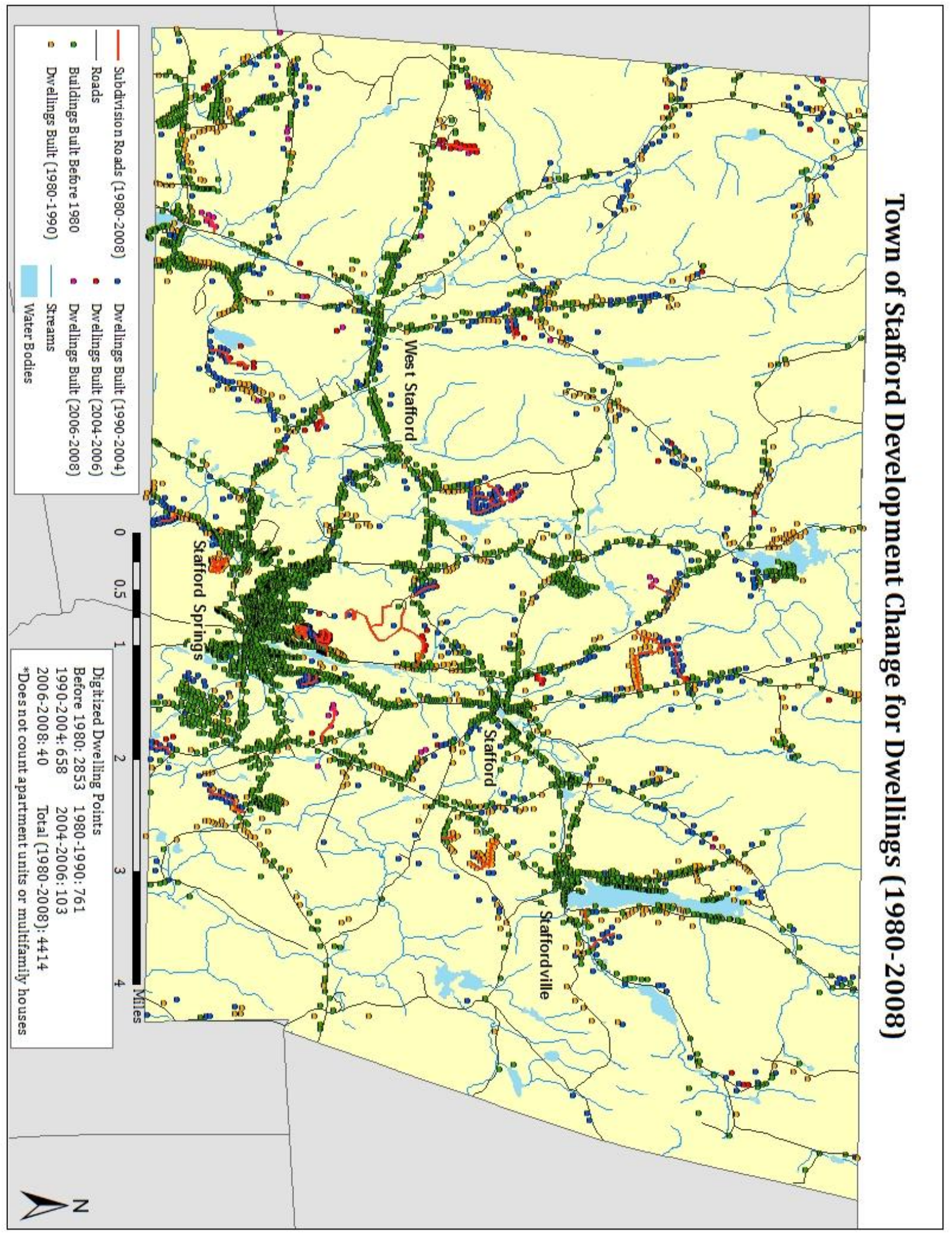

Figure 9. This map shows spatial distribution of home construction in Stafford between 1980 and 2008. Each color signifies a particular period of time in which homes were constructed. 


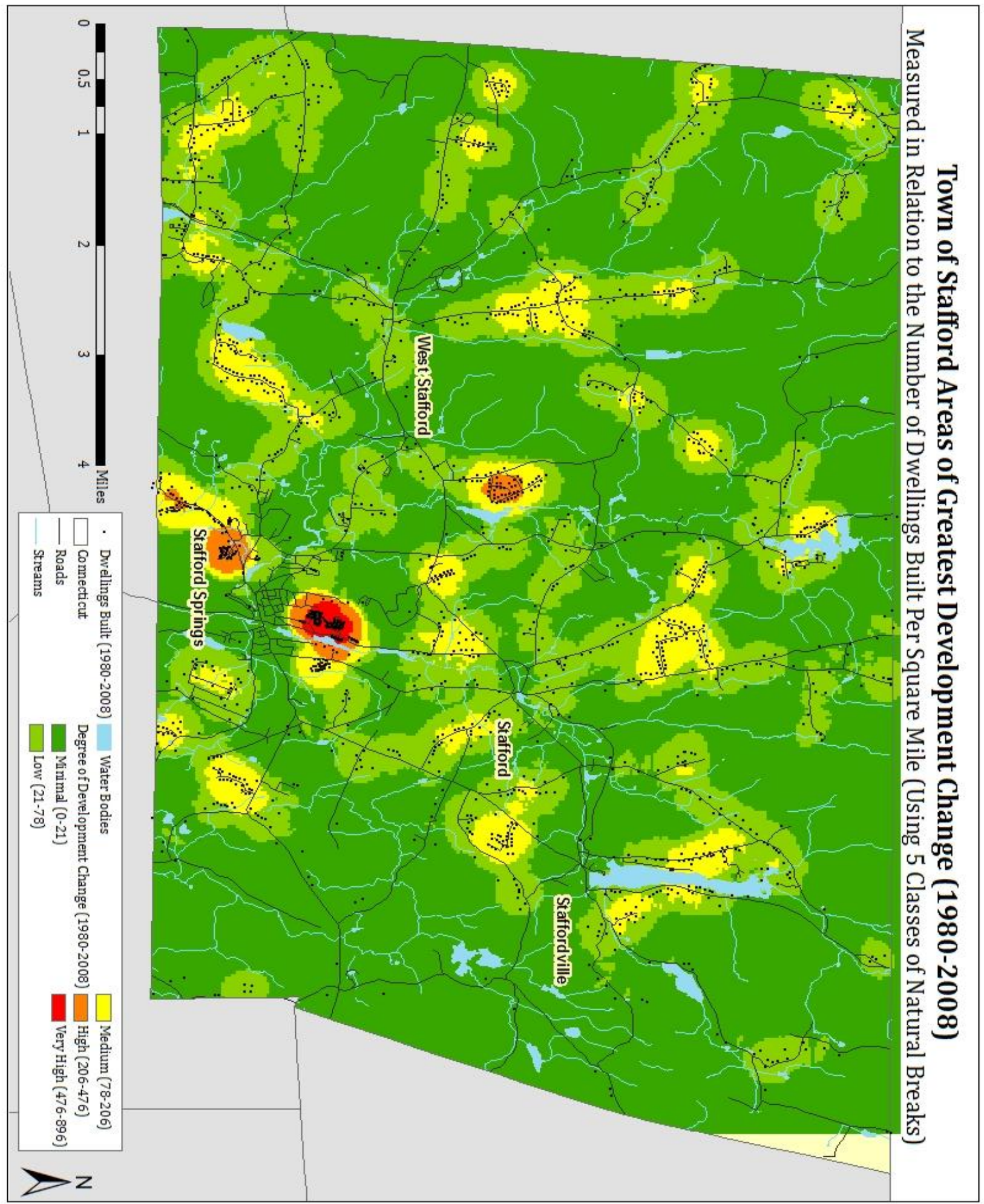

Figure 10. The yellow, orange, and red colors indicate locations of greatest development change as measured by the number of new houses per square mile that were constructed between 1980 and 2008. Unlike development in the early $20^{\text {th }}$ Century, the last 30 years have seen significant unorganized and decentralized residential growth outside the existing urban and village centers. 


\section{Focus Groups: Perceptions of Change and Rural Character}

The results of the focus groups, interviews, and participant observations suggest that rural character and planning are important to residents of exurban New England. However, significant barriers to planning for rural character remain, especially because rural character means different things to people. Three one-hour focus group forums were held at the town's public library during July 2009. Those in attendance were active community members who greatly enriched the discussion and brought forth highly relevant commentary. Participants in the focus groups included members of the Planning and Zoning Commission, Open Space Advisory Committee, Inland Wetlands Committee, Plan of Conservation and Development Advisory Committee, and the West Stafford Fire Department. Several large landowners from rural areas of town attended and commented on their perceptions of landscape change and opinions concerning conservation initiatives. Despite advertising using local printed media and word of mouth, only 15 people attended and participated in the three focus group sessions. Consequently, only qualitative results and participant commentary will be discussed in this paper.

\section{Perceptions of Development Change}

Most of the focus groups participants recognized that the town of Stafford had experienced a generally modest and consistent pattern of residential development between 1980 and 2008, but was nevertheless seeing dramatic land use changes. Not everyone, however, agreed that these changes were necessarily deleterious for the town or its character. While many of the focus group attendees were concerned about Stafford becoming the next suburb of Hartford or Springfield, most people recognized that the town had to grow in order to compete and survive in the region. Even some of the more environmentally conscious participants agreed with business advocates that the town should promote the expansion of light industry and commercial development in place appropriate areas. Nonetheless, most people cited singlefamily housing developments along scenic country roads and new subdivisions in outlying areas as one of the most noticeable landscape changes of the last thirty years.

People concerned with an increase of residential development had a plethora of different reasons for their views. Some were worried about environmental and sustainability issues related to residential development, specifically, forest fragmentation, wildlife habitat destruction, 
and surface and groundwater pollution. Traffic congestion, increase noise, and disagreements with new residents were the primary quality of life issues discussed. Although people who valued the attractiveness and tranquility of a rural landscape were more likely to perceive landscape changes, a few focus group participants were honest and simply did not like change. For these long-time residents, their choice to move to rural Stafford was a response to their dislike of suburban life. Consequently, even subtle changes unnoticed by most people, such as a new "land for sale" sign was enough to grab their attention. Those who perceived development change to be a problem generally were people who lived in more rural areas of town and feared or disliked change. Surprisingly, while environmental degradation was an important issue for some, quality of life issue changes (i.e. increased traffic) got most peoples' attention.

\section{Rural Character Means Different Things to Different People}

For many focus group participants, Stafford's diverse landscape of urban, suburban, and rural areas made defining rural character more difficult. For example, people who resided in the more urbanized mill town villages had different perceptions of what the quintessential exurban New England landscape should be when compared to residents that lived in the rural sparsely populated parts of town. Several focus group participants who lived in the urban area of Stafford Springs valued the old Victorian houses, textile mills, large town park, and walkablity of the Main Street shopping district. While many of them did not want to see the rural areas of town suburbanized, these urban residents thought that the small village and urban mill town feel was an important aspect of New England character that should not be dismissed.

On the other hand, rural focus group participants overwhelmingly viewed cities and mill towns as aesthetically unappealing and dying places. These people tended to value a mixed forested and agrarian landscape prevalent in the early to middle twentieth century where houses were not directly next to each other on perfect manicured lots and cultural features such as town greens (commons), tree-lined country roads, and stonewalls were preserved. For many, the quintessential landscape was that of their childhood. Nonetheless, even rural residents could not agree on what rural character really meant to them. Some viewed rural character in an environmental or conservationist context where forest size, wildlife habitat diversity, and availability of natural resources differentiated between the rural and exurban landscape. Others, 
however, simply viewed "rural" as an aesthetic characteristic or a quality of life issue. One rural resident adamantly proclaimed that "rural is when you have privacy and can't see your neighbors." Despite widespread agreement that uncontrolled growth is a problem, many were unable to agree on a general concept of what defines rural character in New England.

Reaching a consensus on a broad definition of rural character was difficult. Nonetheless, discussing desirable and undesirable landscapes in Stafford helped indirectly highlight places people valued or disliked. Overwhelmingly, individuals who attended the focus groups first chose the more rural, rugged, sparsely populated, and visually appealing parts of northwest and northeast Stafford along the Massachusetts border where large blocks of public and private forestland, narrow valleys, small streams, and farmland remain devoid of intense residential development as most favorable. One person characterized rural Stafford as an "oasis from the monotony of ordinary suburban Connecticut sprawl." Several landowners who own several hundred acres in this favorable area commented, "Living here feels like Vermont except you're only twenty to thirty minutes away from several major cities and suburban shopping areas." Other features or areas that participants valued or found desirable were the several recreational lakes, small farms scattered among woodlands, and the smaller "mill" villages in the central and northeast parts of town. While most people preferred places that were less influenced by human activity, the small town village-feel was still highly desirable.

There was generally less of a consensus for places and landscapes people found undesirable. Some vocal people affirmed that strip mining/gravel operations and ridgeline development were aesthetically displeasing and major threats to community character. Other people mentioned "sprawl" as being unwanted, especially when subdivisions fragmented forestlands, new houses were built on open fields or pastures, and land beside picturesque country roads became subdivided every 200 or so feet to conform to Euclidean zoning. A few were concerned about increased development around Stafford's two largest lakes (Staffordville and Crystal Lakes) making these once desirable places undesirable. More importantly, several people continuously commented that residential development on small family farms was undesirable. Although this study's focus was primarily on rural character in terms of landscape change, some people who themselves professed to growing up on a farm were most concerned 
about the town's social, political, and economic changes as a direct consequence of suburban growth in agricultural areas. Thus, while landscape aesthetics were important, other social, political, and economic issues appeared to underlie many of the participants' opinions concerning rural character. The biggest disagreement among the focus group participants pertained to the urban Stafford Springs area. People who viewed Stafford Springs favorably also tended to dislike large-lot subdivision of land more than those people who viewed the urban areas unfavorably. Several rural residents, for example, preferred conventional large-lot residential development to higher density compact or mixed use development, even if it preserved more undeveloped land.

\section{Compatible Rural Residential Development}

There were not enough people at the focus group sessions to correlate responses statistically. Showing eight photographs of four different types of development scenes found in several nearby towns nevertheless proved useful when trying to figure out the type or types of development residents preferred or felt was most compatible to the character of Stafford. Showing both ground-based photography and aerial imagery stimulated additional conversation among the focus group members. While some people's preference and compatibility rankings did not change even after seeing the aerial view, those people's rankings that did change overwhelmingly became more negative (i.e. less favorable or incompatible). Viewing the aerial imagery made several people look at residential development as a town-wide or regional phenomenon rather than just in the single parcel context.

Large-lot single-family dwellings along a dirt road (Location A) and large-lot singlefamily dwellings on a dead end cul-de-sac in the woods (Location B) were most preferred and viewed as compatible. Although several land use committee members voiced their concerns about building new houses on dirt roads in terms of functional inefficiencies and negative effects to the town (i.e. increased maintenance and cost of infrastructure improvements), others liked these scenes simply because they fit better into the surrounding environment and were often shielded from main roads. One resident exclaimed, "New houses are going to be built anyway so why not have them hidden in the woods on large lots." Several environmentalists and 
conservationists, however, suggested that these scenes would be more compatible if the developer had to set aside a certain amount of open space.

The one scene that participants overwhelmingly disliked was the higher density suburban cluster housing from Location C. However, several people who lived in Stafford Springs liked this type of development from a sense of community standpoint. Once again, the dichotomy between the preferences of rural and urban residents became apparent. While some people eventually agreed that higher density development coupled with open space requirements could help preserve more undeveloped land, one individual brought up an important point. "Should we care more about saving open space or preserving our traditional way of life?" Clearly people were divided over whether environmental issues should dominate discussions of rural character, especially when other social and economic issues influenced many peoples' opinions concerning residential growth. When discussing the scene of the conventional subdivision built on top of a mountain from Location D, many people were adamantly opposed to ridgeline development because houses on the horizon greatly detracted from the rural feel. Nonetheless, some confessed that they would like living on a mountain because of the spectacular views. Thus, the landscape preference and compatibility surveys also emphasized the challenge of balancing individual freedom and choice with the goals and desires of the entire community.

\section{Concern about Sprawl, Unsure about Planning}

The majority of focus group participants agreed that unplanned residential growth was not in the best interest of the town or its residents. At the same time, however, some people who thought growth was a potential problem were still hesitant about increasing the role of land use planning. Residents and landowners on both ends of the political spectrum, whether they perceived development change to be a problem or not, tended to value the bundle of sticks related to property-rights that ensures a landowner the right to develop. One landowner who would have theoretically liked to conserve his land even said, "I hate to see all this new development and see the character of the town change but added regulations would just make things harder for my family and me. What if I need to sell my land in the future?" Other residents complained that the overall reluctance of elected officials, past and present, to address issues pertaining to municipal planning and the emotionally charged atmosphere of a small town 
made them unwilling to go to any land use related meetings. One woman who was at first reluctant to come to the focus groups exclaimed, "town politics make a lot of people unwilling to discuss planning because they feel that there will never be a compromise."

Heated personal exchanges and decades of reactionary zoning have made many residents cynical about the possibilities of planning. Some people, however, believed Stafford still has the opportunity to improve proactive land use planning efforts before widespread suburban residential growth threatens its character. Advocates for responsible development and conservation asserted that additional planning would benefit both the town and its residents. According to several focus group participants, most opposition to development or growth in Stafford over the years has been on a case-by case reactionary basis for controversial projects such as the 2006 Wal-Mart Supercenter proposal that ended with the town enacting a 40,000 square foot limit on the size of commercial structures (Town of Stafford Revised and Consolidated Zoning Regulations). Although there were some who clearly did not want change, most people at the focus groups agreed that Stafford needed to both (1) attract new commercial and industrial business to increase the tax base and (2) simultaneously preserve the character of the community. Yet advocates of rural preservation were willing to support efforts to increase commercial and industrial development in appropriate areas of town as long as there were equally relevant efforts to protect and preserve outlying rural areas. Nonetheless, many people conceded that personal politics and special interests are hard to eliminate in a small town such as Stafford. "While some of it may be apathy, the reality is that a lot of people just don't want change or their taxes to increase. Most people are only concerned about themselves and how the government's actions affect them."

Some people at the focus groups also discussed how Stafford's diverse landscape of large contiguous tracts of forestland surrounded by small farms, historic town greens, and mill towns makes agreeing on a way to plan for rural character difficult. Even those people who supported planning for rural character or additional municipal planning endeavors, disagreed over what landscape best defined Stafford. Because urban residents were more likely to support new urbanist ideals of walkability, housing diversity, parkland, and the small town urban community feel, they sometimes clashed with rural residents who had different priorities or suggestions to 
improve the town. One resident at the focus groups said, "Planning for rural character is all well and good but try explaining that to someone who views Stafford from an urban or suburban point of view." In the end, the focus groups highlighted the ideological and geographic divisions of the populace.

Interviews and Observations: Moving Forward to Plan for Rural Character

While many stakeholders agreed that planning for rural character could be advantageous for Stafford, they also admitted that many barriers would need to be overcome before the public would support it. In the summer of 2009, volunteers from a variety of boards and committees under the auspices of a newly formed Plan of Conservation and Development Advisory Committee were working on a modern update to the town's outdated comprehensive plan, which was last revised and written in 1972. The plan was only in its draft stages during the course of this research. Nonetheless, the committee and a planning consultant intended to present their recommendations to the public later for review. Despite historical antipathy and apathy toward land use regulations beyond zoning, several groups in town have been actively pursuing expanding the role of planning.

Many people who were interviewed supported additional planning measures, innovative subdivision designs, and increased environmental regulations because they believed environmentally sensitive land needed protection from development pressures.

Overwhelmingly, these supporters cited single-family housing developments, as the greatest threat to the rural character of the town's outlying areas. At the same time, most supporters of additional planning initiatives also wanted responsible development. One resident, for example, said she would "like to see a strong plan (10-20 year) that will protect our natural resources, encourage industry, but also encourage residential development in appropriate places.” Many residents, landowners, and other stakeholders also discussed the practical, functional, and economic benefits of additional planning endeavors for Stafford and its residents. The elected First Selectman, who once was a developer and real estate agent, said his priority in land use matters was increasing the industrial and commercial tax base in the community. For example, as of June 2009, Stafford received 84 percent of its tax revenues from residential properties, with only a remaining 16 percent coming from commercial and industrial properties. Single-family 
dwelling development, while important to the local economy, costs the town more money than it brings in when calculating education, infrastructure, and public safety costs (i.e. a single-family house with children pays on average $\$ 5,000.00$ a year in taxes to the town but may cost the town $\$ 18,000.00$ in education fees). Thus, some saw controlling residential development as important to maintaining town services without significantly raising taxes.

The Open Space Advisory Committee invited several large landowners in town to attend an informational meeting where they could discuss feelings of land conservation and planning for rural character. Of the five landowners who attended the meeting, all were supporters of land conservation. Several were passionate about having the town of Stafford get more involved with land use planning and conservation through stricter regulations and incentives. Because surrounding towns have adopted stricter development codes, the fear among these landowners was that Stafford would continue to experience an influx of new development because of its weaker and less restrictive regulations. Others, on the other hand, did not trust the government getting involved in the business of conservation or did not have the confidence that they would be helpful. Nevertheless, the landowners believed that the key to conservation and rural planning is "bringing an awareness of the issue first to landowners and then the townspeople." There was an overwhelming sentiment at this meeting, however, that large landowners should work together at the grassroots level with or without the town's help. Ultimately, the landowners agreed that the town should educate townspeople of the need for more open space, encourage large landowners to work together, develop an open space land priority list, revise zoning regulations, add additional subdivision requirements, create and implement overlay zones, and encourage commercial/industrial development in appropriate areas to increase the tax base.

Even those who supported rural character planning and responsible growth admitted that trying to implement new rural character planning initiatives would not be easy. Community members working on the Plan of Conservation and Development were quick to comment that many people in town were unaware of the differences between zoning regulations and planning for a comprehensive plan. Historically, according to one committee member, planning has been regularly associated with zoning and sometimes used interchangeably in local conversation. Consequently, the common sentiment among the committee members was that the average 
resident of the town may not be familiar with the newer concepts or intentions of land use planning (i.e. Arendt's Rural by Design) because Stafford did not need comprehensive planning in the past. Nonetheless, "People are worried about more regulations but they don't understand that we [the town] need to base our zoning on a comprehensive plan so it's legally sustainable."

Most people who were skeptical about the future prospects of planning for rural character in Stafford brought up economic, demographic, and funding and implementation concerns. When talking to a candidate for public office about views of planning, the individual was supportive of more planning if that meant bringing more jobs and economic opportunities to the town. One common idea was best summed up in this statement, "We're poorer than the other surrounding towns. We have to grow or we will not be able to compete or even survive." For many politicians and their constituents, redeveloping empty factory buildings and commercial stores was understandably a higher priority than the conservation of land or the preservation of rural character. At the same time, a vocal minority who wanted both responsible growth and preservation of rural character looked to the experiences of surrounding towns. "It's great that they [other towns] are trying to preserve rural character but it's too late. Stafford is going to end up the same way if we don't take any action." Nonetheless, nearly everyone agreed that limited funds and resources make rural character planning extraordinary difficult, especially when there is a constant struggle over the allocation of money. According to one town employee, unlike wealthier suburban towns that can afford to raise taxes and hire full-time planners, Stafford sometimes struggles to fund nonessential initiatives or services, especially during an international economic downturn.

\section{DISCUSSION}

\section{Challenges of Planning for Rural Character in Exurban New England}

Stafford embodies the typical working class exurban fringe community caught between the prospects of economic growth and landscape conservation. Although Randall Arendt and others first made conservation development and planning for rural character famous nearly two decades ago in the Connecticut River Valley of Massachusetts, development patterns in Stafford imply that some areas of exurban New England continue to struggle with sprawl and loss of rural 
character. Between 1980 and 2008, Stafford, much like other southern New England towns on the suburban periphery, has experienced an increase in housing construction occurring outside existing village centers, especially along secondary town roads despite only modest population growth. As more houses are constructed along existing roadways, more large platted subdivisions may be constructed, thus further altering sense of place and rural character. Seeing that most of the development between 1980 and 2008 did not occur in any specific area of town, the rural character of Stafford's periphery has potential to change significantly in the future, especially if larger privately owned parcels are sold for residential development.

Several major challenges may inhibit implementation of additional rural character planning measures in working class exurban municipalities similar to Stafford, as indicated by focus group and interview responses. Some of these challenges include planning misinformation and development perceptions, political and ideological divides, town demographics, traditions, and priorities, and funding and implementation issues. Most notably, in many smaller New England towns where political fragmentation is common, planning is often associated with zoning and sometimes used interchangeably in local conversation. In some cases, rural residents may view planning simply as an additional set of regulations designed to encourage further government intrusion and regulation. Many residents in these areas may not be familiar with the concepts or intentions of land use planning, especially, if they live in places that did not need comprehensive planning in the past. Consequently, this indicates that the planning literature may underestimate the need to educate the local populace about the benefits of planning in places similar to Stafford.

This research implies that people who perceived development change to be a major problem tended to support more comprehensive and proactive planning efforts, as suggested by Walker and Ryan (2008) in their study of a small town in Maine. Therefore, perception of landscape alteration, or a general understanding of one's surroundings may be critical to promoting land use change awareness needed to advance rural character planning. Many of the rural landscape preference photo questionnaires, such as the ones employed by Ryan (2002), Ryan (2006), Sullivan (1994), Tilt et al. (2007), and Walker and Ryan (2008) used only ground photographs of new development and landscapes. In a place such as New England where 
development may be hidden by foliage or hilly terrain, people may better understand the extent of landscape change if they are able to view aerial imagery, especially because this can show regional land use patterns beyond the confines of a single municipality. Despite the prevalence of aerial imagery in online mapping applications such as Google Maps, many rural residents, especially older people, are unfamiliar with the newer internet or GIS technologies. For example, one participant, who openly admitted that she had problems visualizing the local geography, felt that the maps and photographs at the focus groups, helped her better comprehend how the landscape of the town was changing. Because perception is the first step toward understanding the need for planning, newer geospatial technology could be an important part of future rural planning education.

Deep-rooted political and ideological divides can make consensus building needed for planning even more difficult. In a world of partisanship and special interests, cooperation may only be possible by suppressing deep differences or sacrificing certain objectives in order to achieve the most important goals (Levy, 2006). For example, differences between the environmentalists and business-minded people in Stafford often inhibit any efforts to comprehensively plan at the municipal level. At the focus groups, the number one issue discussed was how to attract new commercial and industrial business to increase the tax base and simultaneously preserve the character of the community. Even if advocates of rural preservation were willing to support efforts to increase commercial and industrial development in appropriate areas of town as long as there were equally relevant efforts to protect and preserve outlying rural areas, issues of trust and equity made some people reluctant to compromise. Nonetheless, because the focus groups concentrated more on the future rather than on past actions or decisions, many participants were more willing to speak honestly. After one of the focus groups concluded, two participants, who came from opposite ends of the political spectrum, continued to engage in a civilized discussion in the parking lot of the meeting area. This was a clear indicator that this research method was effective at getting people to discuss the issues while simultaneously bridging political or ideological divides. The focus group discussions suggest that exurban communities may want to focus on positive realistic opportunities that would benefit more than just one subset of the population. Dwelling on controversial past development projects, proposing radical changes to government policies, or mentioning personal and political 
disputes may only further divide and isolate people of opposing ideologies. Much of the land use decisions in rural areas are reactionary in nature. Thus, to transcend political and ideological divides effectively, important land use discussions need to be made long before a specific development project is proposed.

Smaller working-class communities on the rural-urban fringe can have different priorities than more suburbanized towns that have already lost significant land to development. Residents of exurban municipalities typically rely more on blue-collar jobs related to natural resource extraction, construction, forestry, and manufacturing than their suburban white-collar counterparts. Not only does Stafford, for example, have a lower median household and per capital income than surrounding towns, but according to the 2000 United States Census, nearly 19.1 percent of the town's workforce is employed in textile, water filter, and printed circuit manufacturing, 9.9 percent in construction, and 8.8 in real estate services. This prevalence of construction and real estate jobs makes enacting additional land use planning more difficult, especially when people are concerned that additional regulations could adversely affect their employment and livelihood. Thus, rural residents who often depend on the extraction and use of natural resources may be more likely to support economic expansion at the expense of environmental protection, as suggested by Freudenburg (1991) in Rural Urban Differences in Environmental Concern. While this does not mean that rural residents do not value the environment, it implies that they may be more likely to support specific environmental issues that have a local effect on their lives. Consequently, in order to plan for rural character in these places, not only does the loss of rural character need to be perceived as a problem, but also residents need to feel that it will somehow adversely affect their everyday lives.

Even if people support planning endeavors, a lack of funding or appropriate implementation methods may inhibit any land use policy changes from taking place. Comprehensive planning can cost tremendous time and money, two resources currently inhibiting Stafford's planning agenda. A prime example of this is the Plan of Conservation and Development Advisory Committee, composed of community volunteers, who must work with a limited budget. Although the town hired a planning consultant to help them update their comprehensive plan, the town had to cut the budget needed to retain the planner to pay for other 
essential services. Limited funds and resources make rural character planning extraordinary difficult, especially when there is a constant struggle over the allocation of money. Despite hiring a part-time planning consultant to aid in the revision of the town's comprehensive plan, budget cuts have required citizen volunteers to complete most of the work. Therefore, even implementing the suggestions from the finished comprehensive plan may take time because most people working on land use revisions are volunteering evenings outside of their own work and family time.

\section{Collaborative Learning Implications}

Most people who attended the focus groups or participated in the interviews were concerned about sprawl altering the character of Stafford. While the focus groups were generally effective at getting participants to discuss perceptions of development change, rural character, landscape preferences, and thoughts concerning municipal planning in a politically neutral stress-free environment, even people who saw sprawl as a problem where unsure what direction rural planning should take. Consequently, this study indicates that a concern for sprawl does not always lead to a desire for more planning. In the case of Stafford, people were often divided over whether environmental issues should dominate discussions of rural character, especially when other social and economic issues influenced many peoples' opinions concerning residential growth. The community's inability to agree on a common definition of rural character made it difficult for everyone to come together to agree on what planning measures were needed. For example, some people were mainly interested in promoting more residential and commercial growth with stricter aesthetic controls while others wanted simply wanted to conserve more undeveloped environmentally sensitive land. Because the development pressures many exurban communities on the urban-rural fringe are experiencing may be relatively new, residents in these towns may be confused or unsure about how they feel concerning the change. Thus, future research may need to address the difficulty of defining rural character, specifically within the context of the ever-changing exurban fringe community.

Stafford exemplifies the modern challenges of diffuse exurban development where residential development often outpaces population increase and different perceptions of development change and definitions of rural character make planning for rural character difficult, 
especially when the merits of planning are misunderstood or unknown. Focus groups can be a helpful venue where residents and other stakeholders can discuss their misconceptions and concerns related to planning when planning for rural character. Focus groups, however, may only be effective if major community concerns are identified early on to help defer criticism. In the case study, some people skeptical of planning for rural character were primarily worried about increased government intrusion, lower property values, and higher taxes. Most skeptics also cited the existence of the decades old zoning/subdivision regulations as proof that "planning" was already being done. This is why it may be crucial to highlight the differences between existing zoning codes, which are often costly and reactionary in nature, and proactive long-term planning. Concerns of increased government intrusion, especially in terms of higher taxes are often a major concern in rural areas, as highlighted by Hamin et al. (2006) in a study of neighboring Massachusetts. Some landowners, especially the elderly on fixed incomes, cannot afford paying high property taxes and often sell their land to a developer in order to pay bills. Consequently, taxation is a critical issue that needs to be at front and center of the rural planning debate, something that is often ignored in the literature.

Planning for rural character should not just be about aesthetics or environmental protection. The results of this study suggest that a plan may also want to emphasize land use efficiency and functionality, as well as being legally sustainable in order to gain wider support in a working class community unfamiliar with proactive planning. Responses from the focus groups and the interviews indicate that Stafford and other similar municipalities should consider finding, delineating, designing, and promoting appropriate commercial and industrial properties and then revising zoning residential regulations to encourage infill development in populated areas and conservation development in outlying rural areas. At the same time, these towns may also want to consider working with willing landowners to voluntary protect valuable and sensitive lands and preserve rural character in designated areas. If possible, future land conservation efforts should be directed to areas where larger parcels of unsubdivided land are adjacent to state and private conservation lands. Ultimately, planning for rural character should incorporate realistic and nonintrusive goals that aim to encourage economic development and rural character preservation while simultaneously ensuring that infrastructure, public works maintenance, education, and public safety costs are kept at reasonable levels. While Arendt, 
Ryan, and others have written extensively about incorporating these concepts into conservation development plans, more research may be needed to develop more effective ways to convince residents in towns like Stafford that proactive planning may actually save taxpayer money and increase property values. Part of the challenge of promoting conservation development and planning for rural character is convincing landowners that alternative options such as conservation subdivisions can still provide profit without sacrificing landscape aesthetics, community character, or environmental sustainability.

\section{CONCLUSION}

Exurban southern New England has experienced steadily increasing residential development leading to landscape change and loss of rural character, outpacing relatively modest population growth over the last several decades. Although conservation development and planning for rural character have become firmly established in the planning literature over this same period, it remains a challenge for Stafford, like many other exurban communities on the rural-urban fringe, to ensure that new single-family housing development fits into the character of the community. Planning for rural character, however, needs to start at the grassroots level with the support of the residents and landowners, not with the government, planners, or from those people perceived by locals to be outsiders. The case study of Stafford, Connecticut highlights the need for additional research on how to best introduce and implement planning in exurban and rural areas where growth often outpaces planning efforts and reaching a consensus on a broad definition of rural character is difficult. One of the greatest limitations of this study was the low level of focus group participation. While there may have been many reasons for low turnout at the focus groups, the difficulty of encouraging participation in rural communities highlights another important issue that needs to be addressed further in the planning literature. Educating residents and stakeholders about the misconceptions and benefits of planning, as well as advocating pragmatic policies that incorporate rural character planning with themes of land use efficiency, functionality, and economic growth potential may be necessary to acquire community support in many working-class exurban municipalities similar to Stafford. Government support of rural character planning may be needed in the future. However, real change can only start with the rural landowner. Consequently, those passionate about conserving 
rural character may need to step back periodically and just listen to the concerns of the landowners because the future is in their hands. 


\section{REFERENCES CITED}

Arendt, R., 1999. Growing Greener: Putting Conservation into Local Plans and Ordinances. Washington, DC: Island Press.

Arendt, R., Brabec, E.A., Dodson, H.L., Reid, C., \& Yaro, R.D., 1994. Rural by Design: Maintaining Small Town Character. Washington, DC: American Planning Association.

Connecticut Economic Resource Center. (2006). Town of Stafford Land Use Economic Development Analysis. Hartford, CT: Author.

Connecticut Office of Policy and Management. (2005). Conservation and Development Policies Plan for Connecticut. Hartford, CT: Author. Retrieved from http://www.ct.gov/opm.

Crawford, T. W. (2007). Where does the coast sprawl the most? Trajectories of residential development and sprawl in coastal North Carolina, 1971-2000. Landscape and Urban Planning, 83(4), 294-307.

Daniels, T. (1999). What to Do About Rural Sprawl? American Planning Association Conference April 1999, Seattle, WA.

Dowling, T. J. (2000). Reflections on urban sprawl, smart growth, and the Fifth Amendment. University of Pennsylvania Law Review, 148(3), 873-887.

Epstein J. Payne K. Kramer, E. (2002). Techniques for mapping suburban sprawl. Photogramm. Eng. Remote Sens., 63(9), 913-918.

Freudenburg, W. R. (1991). Rural Urban Differences in Environmental Concern. Sociological Inquiry, 61(2), 167-198. 
Gonzalez-Abraham, C. E., Radeloff, V. C., Hammer, R. B., Hawbaker, T. J., Stewart, S. I., \& Clayton, M. K. (2007). Building patterns and landscape fragmentation in northern Wisconsin, USA. Landscape Ecology, 22(2), 217-230.

Hamin, E. M., Steere, M. O., \& Sweetser, W. (2006). Implementing growth management. Journal of Planning Education and Research, 26(1), 53-65.

Hasse, J. (2004). A Geospatial Approach to Measuring New Development Tracts for Characteristics of Sprawl. Landscape Journal 23(1-04), 52-67.

Hasse, J., \& Lathrop, R. (2003). A housing-unit-level approach to characterizing residential sprawl. Photogrammetric Engineering and Remote Sensing, 69(9), 1021-1030.

Hoffhine Wilson, E., Hurd, J. D., Civco, D. L., Prisloe, M. P., \& Arnold, C. (2003). Development of a geospatial model to quantify, describe and map urban growth. Remote Sensing of Environment, 86(3), 275-285.

Levy, J.M., Contemporary Urban Planning: Seventh Edition (Upper Saddle River, NJ: Pearson, 2006), 345-362.

Ryan, R. L. (2002). Preserving rural character in New England: Local residents' perceptions of alternative residential development. Landscape and Urban Planning, 61(1), 19-35.

Ryan, R. L. (2006). Comparing the attitudes of local residents, planners, and developers about preserving rural character in New England. Landscape and Urban Planning, 75(1-2), 522.

Sullivan, W. (1994). Perceptions of the Rural-Urban Fringe - Citizen Preferences for Natural and Developed Settings. Landscape and Urban Planning, 29(2-3), 85-101.

Tilt, J. H., Kearney, A. R., \& Bradley, G. (2007). Understanding rural character: Cognitive and visual perceptions. Landscape and Urban Planning, 81(1-2), 14-26. 
Torrens, P. M. (2008). A toolkit for measuring sprawl. Applied Spatial Analysis and Policy, 1(1), 5-36.

Town of Stafford. (2009). Draft Plan of Conservation and Development. Stafford Springs, CT.

Town of Stafford. (2008). Revised and Consolidated Zoning Regulations. Stafford Springs, CT: Author. Retrieved from http://www.staffordct.org/building.php.

Town of Stafford. (2006). Subdivision Regulations. Stafford Springs, CT: Author. Retrieved from http://www.staffordct.org/building.php.

Walker, A. J., \& Ryan, R. L. (2008). Place attachment and landscape preservation in rural New England: A Maine case study. Landscape and Urban Planning, 86(2), 141-152.

Wolman, H., Galster, G., Hanson, R., Ratcliffe, M., Furdell, K., \& Sarzynski, A. (2005). The fundamental challenge in measuring sprawl: Which land should be considered? The Professional Geographer, 57(1), 94-105. 